\title{
The effects of fiscal policy after the global recession: assessing the evidences
}

\author{
LUIZ FERNANDO DE PAULA \\ MANOEL CARLOS DE CASTRO PIRES*
}

This paper offers a commented review of the most recent empirical studies of the effects of fiscal contraction on economic growth, which have helped underpin the prescription that fiscal policy should be expansionary in coming years in order to contain economic semi-stagnation in the developed countries. The paper shows that there is ample literature showing that fiscal expansion helps the economy grow, and that fiscal contraction tends to reduce output and employment in the short term.

Keywords: fiscal consolidation; counter-cyclical policy; international financial crisis. JEL Classification: E61; E62; H3.

\section{INTRODUCTION}

The adoption of counter-cyclical policies in a number of countries, since the financial crisis, has renewed economists' interest in the impacts of fiscal policy on economic growth. At first, discussions of the effectiveness of fiscal stimuli sparked major controversy leading to extreme polarisation between positions for and against such policies. With time a fresh body of evidence pointed to fiscal policy having significant impact as a counter-cyclical economic policy tool to address the effects of the 2007-2008 financial crisis.

A second movement saw countries embarking on a process of fiscal consolidation. At that time there was a mix of positions: some argued that it was too early to withdraw fiscal inducements and that the economy would slow; others advocated withdrawal as necessary to prevent the trajectory of public debt from becoming

\footnotetext{
* Respectively, Professor of Economics at the University of the State of Rio de Janeiro (UERJ) and Researcher of the National Council of Technological and Scientific Development (CNPq). Email: luizfpaula@terra.com.br; Researcher of the Institute for Applied Economic Research (IPEA), currently at the Executive Secretary of Brazil's Ministry of Finance. Email: manoel.pires@ipea.gov.br. Submitted: 14/November/2011; Approved: 11/December/2012.
} 
unsustainable, which would undermine market confidence in the economy and thus curb economic growth (IMF, 2010). This latter line of reasoning rested on the evidence in favour of expansionary fiscal contractions. Gravelle and Hungerford (2011, p.1) sums up the challenge of the policy makers:

"the policy challenge is a trade-off between the benefits of starting to address the debt problem earlier versus risking damage to a still-fragile economy by engaging in contractionary fiscal policy, or failure to continue with expansionary fiscal policy".

The brief recovery in the world economy that began in 2010 cut short the discussion as most developed countries began a process of fiscal consolidation. According to the new evidence, and not uncoincidentally, economic activity slowed once again, raising the question of whether that process had not been premature. This short paper offers a brief commented review of the most recent empirical studies of the effects of fiscal contraction on economic growth which have helped underpin the prescription that fiscal policy should be expansionary in coming years in order to contain economic semi-stagnation in the developed countries. For this purpose, the paper is divided in three sections, besides this introduction. Next section discusses briefly the argument of "expansionary fiscal contraction" and reports the criticism of some authors on this hypothesis. The third section shows recent evidence on expansionary fiscal policy. Finally, fourth section concludes the paper and extracts some policy lessons.

\section{ARE FISCAL CONTRACTIONS CONTRACTIONARY OR EXPANSIONARY?}

The idea that fiscal contraction can be expansionary found empirical support in a series of studies that gave a rationale for its expansionary effects on the basis that fiscal contraction is able to boost private sector confidence and encourage new decisions to consume and invest through a "crowding-in" effect on private enterprise. In terms of theory, that argument rests on the Ricardian equivalence theorem according to which, assuming rational agents, public spending will merely displace private spending, leaving the level of aggregate demand unaltered; alternatively, a reduction in public spending will stimulate private spending, because the perceived government commitment to fiscal consolidation will increase confidence among rational agents. ${ }^{1}$ Therefore, Ricardian equivalence implies that fiscal consolidation has no impact on economic activity, as changes in private demand exactly offset

\footnotetext{
${ }^{1}$ However, a reduction in public spending may depress economic activity and tax revenues to such an extent that the fiscal deficit shrinks only slightly or not at all. Particularly when such reductions are not offset by increased private spending (as is to be expected in situations where agents' expectations are lowered), the prospects of growth are impaired and there will be little effect on the public deficit. For discussion in greater depth, see Sawyer (2012).
} 
changes in government demand. On the other hand, public deficit reduction will increase confidence of consumers and firms, as they expect their future income to be larger, so they will increase their confidence to spend in the present, resulting consequently in increased current spending on consumption and investment. ${ }^{2}$

This line of research was pursued chiefly by Alesina, who, with a series of collaborators, used the concept of 'cyclically adjusted primary budget balance' $(\mathrm{CAPB})^{3}$ in order to separate fluctuations due to the business cycle from those that are discretionary, and to identify moments of major fiscal consolidation in various countries and to correlate these events with the dynamics of GDP in the period following the fiscal adjustment. On the basis of these datasets, they found evidence of improved economic performance in countries that undertook substantial fiscal consolidation. One of the most recent contributions to this type of literature is Alesina and Ardagna (2010), that examines fiscal adjustments ${ }^{4}$ using a panel of 21 OECD countries from 1970 to 2007. These authors define successful fiscal adjustment as a situation in which the three-year cumulative reduction in the debt-to-GDP ratio is greater than $4.5 \%$ points, and find that tax decreases are more likely to stimulate economic growth than spending increases. ${ }^{5}$

This literature had notable impact on economic policy. Sawyer (2012), for example, reports that since 2010 the new (conservative and liberal) coalition government in the UK has made reducing the public deficit a key economic policy goal, regarding it as fundamental to assuring economic recovery: "tackling the deficit will ensure that future generations are not burdened with unsustainable debt and will underpin private sector confidence, supporting growth and job creation over the medium term" (HM Treasury, 2011, p. 34; in Sawyer, 2012, p. 208).

In fact, the empirical support offered by this literature was rather fragile. Firstly, it never went beyond identifying patterns of correlation rather than causality. It is clearly plausible that economic growth may have been responsible for the

\footnotetext{
${ }^{2}$ According to IMF (2010, p. 93), “The notion that fiscal retrenchment stimulates growth in the short term is often referred to as the 'expansionary fiscal contractions' hypothesis. A key factor explaining such effects is an improvement in household and business confidence".

${ }^{3}$ The CAPB is calculated by taking the actual primary balance - non-interest revenue minus non-interest spending - and subtracting the estimated effect of business cycle fluctuations on the fiscal accounts. According to IMF (2010, p. 95), "cyclical adjustment offers an intuitive way of dealing with the fact that tax revenue and government spending move automatically with the business cycle. The idea is that, once they are cyclically adjusted, changes in fiscal variables reflect policymakers' decisions to change tax rates and spending levels".

${ }^{4}$ The authors define a fiscal adjustment as a decrease in the cyclical adjusted primary balance of at least $1.5 \%$ of gross domestic product (GDP).

${ }^{5}$ Although only nine episodes of fiscal adjustment were expansionary and successful, that is about $8 \%$ of the total. Alesina and Perotti (1997), studying both a full sample of OECD countries and by focusing on three case studies (Denmark, Ireland and Italy), found that fiscal adjustments which rely primarily on spending cuts on transfers and the government wage bill have a better chance of being successful and are expansionary, while fiscal adjustments which rely primarily on tax increases and cuts in public investment tend not to last and are contractionary.
} 
improved fiscal results. This point is demonstrated satisfactorily by Jayadev and Konczal (2011). When this type of control is applied, the results do not support the conclusion that fiscal contraction is expansionary.

Secondly, there is the problem that a significant variable was omitted. Both fiscal policy outcome and behaviour of GDP may have been influenced by a missing third variable. Fiscal studies abound in examples, such as rising commodity prices, exchange rate changes favouring exporting countries, relaxation of monetary policy, vigorous growth in civil construction and rising real estate prices etc. When these effects are considered, the results change: when Guajardo et al. (2011) investigated the short-term effects of fiscal consolidation on economic activity in the OECD countries, they concluded that fiscal contractions produce contractionary effects. ${ }^{6}$

Romer (2011) points out that a number of variables are missing from the empirical work of Alesina and Ardagna (2010):

"Unfortunately, there turns to be a lot of omitted variable bias in Alesina and Ardagna's empirical analysis. Some of their fiscal consolidations weren't deliberate attempts to get the deficit down at all. Rather, they were times when the budget deficit fell because stock price booms were pushing up tax revenues. Stock prices were a big omitted variable. They were driving the deficit reduction and were likely correlated with rapid output growth. This omitted variable made it look as though deficit reduction was expansionary, when it wasn't" (Romer, 2011, p. 18).

A third type of criticism relates to the definition or identification of major episodes of fiscal contraction. Indeed, instead of observing the magnitude pure and simple of the respective current fiscal policy indicator, it would be more appropriate to observe whether, when adjusted for the economic cycle, these variations are in fact exogenous. When this type of adjustment is made, the conclusion also favours the contractionary effects of fiscal consolidation.

In this connection, IMF (2010, Ch.3) suggests that the choices made by Alesina and Ardagna, and other authors, bias the results away from contractionary effects. Indeed, this study uses a different methodology that seeks to identify episodes of fiscal adjustment by policy-maker intent. The IMF results show that several exogenous factors may offset the effects of a contractionary fiscal policy during episodes of fiscal consolidation, such as the central bank's adopting an expansionist monetary policy thus buffering the impacts on consumption and investment, an induced devaluation of the domestic currency heightening the competitiveness of net exports etc. When the impact of the fiscal consolidation is considered in isola-

\footnotetext{
${ }^{6}$ In the same connection, Jaydev and Koncazal (2010), analyzing 26 cases of fiscal consolidation, conclude that in most cases "when countries cut in a slump, it often results in lower growth and/or higher debt-to-GDP ratios. In very few circumstances are countries able to successfully cut during a slump, and this happens only when either interest rates and/or the exchange rates fall sharply" (Idem, 2010, p. 1).
} 
tion, controlling for the other factors, the effect on product is contractionary: "A fiscal consolidation equal to one percent of GDP typically reduces GDP by about 0.5 percent within two years and raises the unemployment rate by about 0.3 percentage point. Domestic demand - consumption and investment - falls by about one percent (Idem, p. 94).

Finally, Gravelle and Hurgerford (2011) review the Alesina and Ardagna data and conclude that most of their successful fiscal adjustments took place during fairly favourable economic conditions:

"[The] results suggest that successful fiscal adjustments (as defined by the cyclical adjustment method) occurred when actual output was below potential output, that is, labor and capital resources were fully employed. The U.S. output gap for 2011 is considerably more negative than the average output gap for all unsuccessful fiscal adjustments beginning when actual output was below potential output” (Idem, 2011, p.12).

Therefore, the deficit reductions in the Alesina and Ardagna paper that were considered successful by the authors' measures were associated in most cases with situations in which economies were generally above, or close to, full employment.

Following these new results, the empirical literature has given more attention to the potentially expansionary effects of fiscal policy, endeavouring to understand in what situations this effect can be maximised and seeking new methodologies for this purpose.

\section{SOME RECENT EVIDENCE ON EXPANSIONARY FISCAL POLICY}

There are now several methodologies designed to estimate the impact of fiscal policy on economic activity. One approach that has resulted in high fiscal multipliers seeks to identify the moment and exact magnitude of a fiscal expansion from historical records. Gordon and Krenn (2010) identify the impact of fiscal policy on growth by revisiting US fiscal policy during the period of greatest idle capacity in the economy during World War II, i.e., between 1939 and 1941. Their estimates conclude for a multiplier of 1.8 .

Along similar lines, Ramey (2011a) shows the importance of separating the fiscal policy component that is anticipated by agents from the component that is unanticipated. This distinction helps understand the differences between the neoclassic results (which are closer to the anticipated outcomes) and the Keynesian results (closer to the unanticipated outcomes). Accordingly, in the effort to identify the effects of government spending shocks, her analysis spans a longer period in the US economy, from 1939 to 2008 and, using an SVAR model, concludes that the multipliers range from 0.6 to 1 .

An alternative approach uses non-linear models to identify fiscal policy impact. These studies use the idea that the fiscal multiplier is 'state-dependent', i.e., that its 
impact can vary with the stage in the economic cycle or even with the monetary policy rule - whether it offsets or buttresses fiscal policy. Auerbach and Gorodnichenko (2011) examine this issue for the US economy from 1947 to 2009 by means of a model that relates the size of the multiplier to the economic cycle, concluding that the fiscal multiplier can vary from -0.3 to 3.6, and is larger in periods of economic recession.

The second methodology endeavours to evaluate the effects of fiscal stimuli from microdata. What is sought in this case is to identify how income transfer programmes affect families' consumption decisions. The results of these studies are quite convincing. The decision to consume is positively influenced by income transfer programmes. The problem with these studies is that they do not answer the macroeconomic questions. For example, it is possible that in order to set up a stimulus programme for a given set of consumers the government will have raised taxation on other consumers. Accordingly, although this methodology may be a promising approach for gauging specific fiscal effects, it still remains to be understood what kind of contribution such results can make to the macroeconomic discussion (Ramey, 2011b; Romer, 2011).

\section{FISCAL POLICY GUIDELINES AND FISCAL SPACE: BY WAY OF CONCLUSION}

As seen in this article, there is ample (and growing) literature showing that fiscal expansion helps the economy grow, and that fiscal contraction tends to reduce output and employment in the short term. Although by and large the evidence is amply in favour of adopting expansionist fiscal policies to combat recessions and spells of poor economic growth, discussion of spiralling debt in several countries during the period following the financial crisis raises the issue of fiscal space and the need for exit strategies.

In the first place, this debate has shown a lack of knowledge of the limits on indebtedness. Some countries (such as the United Kingdom since 2010 and even the USA from 2011), which have pursued fiscal consolidation on the argument that it was necessary to control their debt, had no severe financing problems, because they managed to refinance their debts at very near zero interest rates. For those countries, fiscal contraction was indeed premature, in that their economies had entered a weak economic recovery, and there is no reason to believe in the effectiveness of 'crowding in' on private spending. It also has to be remembered that, when debt is issued in domestic currency, constraints on public debt management are much less restrictive, because at the limit the government can issue money to service its debt, which can be done by the central bank's purchasing public bonds.

Another group of countries have more limited leeway to adopt expansionist policies and face serious debt rollover problems. The countries worst affected by the Euro zone, such as Greece, Spain and Portugal, have entered a vicious circle - with fiscal austerity resulting in higher unemployment, in turn leading to larger 
public deficits and greater austerity - and enjoy little in the way of domestic options for stimulating growth. However, these countries were under the clear constraint of not being able to issue public debt in their own currency — and, at least until recently, the European Central Bank's scope for acting as lender of last resort is limited by the prohibition against monetising government debts or purchasing sovereign debt directly. ${ }^{7}$ The results observed in those countries constitute evidence in favour of a more flexible and coordinated economic policy framework which is something the present architecture of the Euro cannot offer.

\section{REFERENCES}

ALESINA, A., and Perotti, R. (1997) "Fiscal adjustments in OECD countries: composition and macroeconomic effects". IMF Staff Papers, 44 (June): 210-48.

ALESINA, A., and Ardagna. S. (2010) "Large changes in fiscal policy: taxes versus spending”. In Brown, J.R. (ed.) Tax Policy and the Economy, vol. 24. Chicago: The University of Chicago Press.

ARESTIS, P., and Sawyer, M. (2011) "The design faults of the economic and monetary union". Journal of Contemporary European Studies, 19(1): 21-32.

AUERBACH, A., and Gorodnichenko, Y. (2011) "Measuring the output responses to fiscal policy." NBER Working Paper 16,311.

HM Treasury (2011), Budget 2011. London: The Stationery Office, HC836.

IMF (2010) "Will it hurt? Macroeconomic effects of fiscal consolidation". In: World Economic Outlook (WEO): Recovery, Risk and Rebalancing. Washington: IMF.

GRAVELLE, J.G. and Hungerford, T.L. (2011) "Can contractionary fiscal policy be expansionary?" CRS Report for Congress. Washington: Congressional Research Service.

GUAJARDO, J., Leigh, D. and Pescaroti, A. (2011) "Expansionary austerity: New international evidence". IMF Working Paper 11,158.

JAYADEV, A., and Konczal, M. (2010) “The boom not the slump: The right time for austerity". New York: Roosevelt Institute. http://www.rooseveltinstitute.org/sites/all/files/not_the_time_for_austerity.pdf

KRENN, R., and Gordon, R. (2010) "The end of the great depression 1939-41: Policy contributions and fiscal multipliers". NBER Working Paper 16,380.

RAMEY, V. (2011a) "Identifying government spending shocks: It's all in the timing". Quarterly Journal of Economics, 126(1): 1-50.

RAMEY, V. (2011b). "Can government purchases stimulate the economy?” Journal of Economic Literature, 49(3): 673-685.

ROMER, C. (2011). "What do we know about the effects of fiscal policy? Separating evidence from ideology”. Speech at Hamilton College. http://elsa.berkeley.edu/ cromer/Written\%20Version $\% 20$ of $\% 20$ Effects $\% 20$ of $\% 20$ Fiscal $\% 20$ Policy.pdf

SAWYER, M. (2012) "The tragedy of UK fiscal policy in the aftermath of the financial crisis". The Cambridge Journal of Economics, 3(1): 205-221.

\footnotetext{
${ }^{7}$ For an analysis of the "design faults" in the construction of the Euro project, see Arestis and Sawyer (2011).
} 